\title{
KEY STRATEGIC ACTIONS TO IMPROVE THE CHALLENGE OF HAZARDOUS WASTE MANAGEMENT IN MOZAMBIQUE
}

\author{
K. FERRARI ${ }^{1}$, R. GAMBERINI ${ }^{1}$, B. RIMINI ${ }^{1} \&$ H. ABACASSAMO ${ }^{2}$ \\ ${ }^{1}$ Department of Sciences and Methods for Engineering, University of Modena and Reggio Emilia, Italy. \\ ${ }^{2}$ Direction of Economic Activities, Maputo Municipality, Mozambique.
}

\begin{abstract}
Waste management is an international issue with a global impact. Industrialised and emerging countries increasingly need raw materials to feed their industries: natural gas, oil, coal, precious minerals and metals. Most African countries are rich in raw materials, which they are powerless to trade on but eager to negotiate with. However, they have difficulty managing the negative effect that these trades produce, due to poor environmental regulations, inadequate waste disposal infrastructures, lack of technology and public bodies with little experience and resources. This situation makes it challenging for some African governments to manage the increasing quantity and types of waste, resulting from the extracting industries and growing urbanization. Furthermore, the benefits are not fairly distributed, whilst the negative impacts, both environmental and socio-economic, of a failing waste management system are widespread and global. We have studied the situation of hazardous waste management in Mozambique as a case study. Mozambique is one of the poorest countries in the world, but is rich in natural resources, which are being exploited by several global companies in recent years, and with insufficient waste management infrastructure. After the analysis of the local condition, this paper aims to trace guidelines to support different stakeholders to make the first coordinated steps towards a better management of hazardous waste.

Keywords: coal, extractive industry, hazardous waste management, key strategic actions landfill, Mozambique, natural gas, natural resources.
\end{abstract}

\section{INTRODUCTION}

All over the world, human activities are consuming the natural resources, deteriorating the quality of the environment. As the world population grows and economies become more industrialised, natural resources, essential to this growth, become scarcer and more costly. As stated at the 2002 World Summit on Sustainable Development [1], a sustainable development is only possible if natural resources are managed in a sustainable and integrated way, at national, regional and global level. If we continue to consume resources at the current rate, in thirty years we will need more than two planets to sustain our economic activities [2]. During the last thirty years, the global consumption of natural resources has grown, reaching almost 70 billion tons in 2008 [3]. Growth has been soaring, rising from $+1,7 \%$ to $+3,7 \%$, when China, Brazil and India began to show important economic growth. According to Myers and Kent [4], this trend will certainly increase, due to the fast rise of new consumer classes in developing and transition countries, who want to achieve the lifestyle of industrialized countries. This situation threatens sustainable economic growth, exacerbating 
environmental problems, such as climate change, biodiversity loss, desertification and ecosystem degradation $[4,5]$.

The world distribution of natural resources is uneven, with Europe as the biggest netimporter, mostly because of the intense exploitation of internal resources and unprofitable mining activity due to high labour and environmental costs [6-8]. The greatest extractor and exporter is Asia, which is also becoming an important consumer. African countries are still rich in unexplored natural resources, precious metal and minerals, with the net-exporting trend up 53\% [7]. Since data about the quantity and availability of these resources is uncertain and incomplete, the World Bank announced in 2014 its plan to map Africa's natural resources [9]. The availability of reliable data could support potential investors in developing countries, produce economic opportunities, create new jobs, increase government revenues, which can be translated into better educational and public health policies. In contrast, the great richness in natural resources could become a threat to the African continent, due to the negative effects that its exploitation could produce, such as soil, air and water pollution, hazardous and non-hazardous waste production, ecosystem alteration. Nevertheless, the negative impact on the environment could be controlled and minimised, the risks of incurring environmental damage, or even disaster, are incredibly high if mining activities are carried out in countries with weak environmental legislation and little monitoring capacity. As stated by the European Community [10,11], international cooperation is necessary to reduce the impact of such activities on the environment, because the mismanagement of such waste may cause pollution of a global and transboundary nature.

This paper examines the state of the art, regarding mining and hazardous waste management in Mozambique, as a case study of developing countries. We have analysed main existing legal framework, policy maker roles and potentiality and the waste management infrastructure. Then, starting from knowledge developed in this particular country, some guidelines are traced to contribute to the efficient design and management of hazardous waste systems in developing poor countries.

\section{MATERIALS AND METHODS}

This paper draws on primary data and experiences gathered from 2014, under the project PROSIGRU, co-financed by the Italian Ministry of Foreign Affairs and International Cooperation and led by the Mozambican Ministry of Land Environmental and Rural Development (MITADER), in partnership with the National Association of Mozambican Municipalities (ANAMM), with the technical assistance of an International non-governmental organisation LVIA - Lay Volunteers International Organization, based in Italy and active in Mozambique since 2006. The project will end in 2017 and aims to enhance the environmental sustainability in the urban areas of Mozambique, improving the governance of the integrated waste management system at national level.

Our study focuses on recent mining activities and on the quantity and type of waste generated, aiming to identify the main future challenges and opportunities to improve the local capacity to manage it. Firstly, we have studied the local context to obtain background information and data to sketch an initial outline of solid and hazardous waste management in Mozambique. We analysed laws, regulations and documents relating to waste management; sectorial studies, along with feasibility studies. We then interviewed stakeholders involved in waste management: policy makers; technicians; private enterprises; international and local associations. The questions were tailored to understand the impact of new economic activities of natural resources extraction, in terms of the waste produced and managed. We then have underlined main problems related to their collection and disposal, particularly regarding hazardous waste. 


\section{RESULTS AND DISCUSSION}

\subsection{Mozambique}

The Republic of Mozambique is situated in southern Africa, bordered by the Indian Ocean to the east, Tanzania to the north, Malawi and Zambia to the northwest, Zimbabwe to the west, and Swaziland and South Africa to the southwest. Over the past two decades, the annual growth rate of Mozambique has reached 7\% and, in 2015, Gross Domestic Product (GDP) grew at a rate of $5.9 \%$, due in part to extractive industries [12]. However, this trend has not reduced poverty: Mozambique is still one of the poorest countries in the world, with a Human Development Index (HDI) of 180 out of 188 countries and territories considered in 2014 [13].

Since its independence from Portugal in 1975, subsistence farming has been the predominant economic activity, not including the only largest foreign investment project of aluminium smelting, still active in the south of Mozambique, close to the capital Maputo. The scenario has changed with the recent discovery of natural gas and coal, which has located Mozambique among the African providers of commodities such as natural gas, industrial minerals and precious metals. The international price of these commodities has recorded a large increase, caused mainly by the high demand from emerging countries, particularly the BRICS (Brazil, Russia, India and China), which are becoming key economic partners in Africa.

\subsection{Natural resources of Mozambique}

Mozambique is rich in natural resources, but the extractive sector is still operating below its real potential $[14,15]$. Despite this, the entry of large multinational companies has boosted the sector since 2010, particularly regarding natural gas and coal extraction. Other resources that are exported are i.e. uranium, titanium, zirconium, gold, gemstones, fluorite and other industrial minerals [15].

One of the biggest investors in coal extraction, which operates in Moatize, Tete province, since 2011, has estimated a capacity of 22 million tons of coal. Regarding natural gas, the recent findings made in 2010 in the offshore area of the deep-water Rovuma Basin, are one of the most important natural gas discovery in the last 20 years and could place Mozambique among the biggest producers, together with the United Arab Emirates and Venezuela [16]. Nevertheless, like other countries rich in natural resources but poor in quality of life and basic services, Mozambique is suffering from the "natural resource curse" [17].

Despite the fact that the government has made an important effort to improve the national infrastructures (ports, roads, railways and power lines) and to revise the legal and fiscal framework, Mozambique still shows a failing score in the Resource Governance Index (RGI), due to its low rankings in terms of reporting practices, safeguards and quality controls, specifically as concerns the environmental impact of production/extraction activities [14]. Notwithstanding, mining is an economic opportunity for Mozambique [16, 18], that however should be correctly designed and managed.

The focus of the paper is on the production of different types and large quantities of hazardous waste, following mining, whose optimized management is addressed here.

\subsection{Waste management in Mozambique}

As demonstrated in several studies [19, 20], the Mozambican government is aware of its weakness in managing local waste. The same conclusion has been obtained during PROSIGRU 
project, and specifically during engagement activities of policy makers. The results obtained are described in the following and refer to two crucial aspects: on one side input data for planning and on the other available landfills for final waste management (since landfill still remains the main management option).

As in most developing countries, there is little reliable data about waste production and composition in Mozambique, if we exclude the capital city Maputo, the first city with a municipal master plan for urban solid waste management, completed in 2008 [21]. The total quantity of waste produced in Maputo was evaluated at 980 tons/day (without fine fraction) with a per capita production between $1 \mathrm{~kg} / \mathrm{pp} / \mathrm{d}$ for the inner and more affluent city centre and $0.56 \mathrm{~kg} / \mathrm{pp} / \mathrm{d}$ for the suburban and poorer zones. The percentage of organic waste is generally high, and vary depending on the area of the city between $54 \%$ and $71 \%$ [21, 22]. If we consider only household waste, in 2012 the collection rate for Maputo was 82\% [21, 23], a high value if compared with the average rate of other cities in developing countries [24-28], which generally range between $30 \%$ and $70 \%$.

Other plans have been designed since 2011 by local authorities and MITADER, the MInisterio de Terra, Ambiente e DEsenvolvimento Rural [29-38]. The data reported on these plans show a marked heterogeneity and low reliability, since it is not always explained how the estimations were made, in particular regarding the amount of waste generated and collected, which in some plans were not evaluated either (Table 1).

Table 1: waste generation and collection data in the main cities of Mozambique (from municipal solid waste management plans - MSWMP). ${ }^{(1)}$ without fine fraction.

\begin{tabular}{lcccccc}
\hline \multicolumn{1}{c}{ City } & $\begin{array}{c}\text { Population } \\
\text { (census } \\
\text { 2007) }\end{array}$ & $\begin{array}{c}\text { Total waste } \\
\text { generation } \\
\text { (tons/day) }\end{array}$ & $\begin{array}{c}\text { Per-capita } \\
\text { waste } \\
\text { generation } \\
\text { (kg/pp/day) }\end{array}$ & $\begin{array}{c}\text { Waste } \\
\text { collected } \\
\text { (tons/day) }\end{array}$ & $\begin{array}{c}\text { Collection } \\
(\%)\end{array}$ & $\begin{array}{c}\text { Year of } \\
\text { MSWMP } \\
\text { design }\end{array}$ \\
\hline Maputo & $1,111,638$ & 980.00 & 0.88 & 760.00 & 77.55 & 2008 \\
Lichinga & 141,724 & 54.00 & 0.38 & & & 2015 \\
Ilha de & 48,063 & 16.60 & 0.35 & 6.70 & 40.36 & 2014 \\
Moçamb. & 206,449 & 124.40 & 0.60 & 47.50 & 38.18 & 2014 \\
Nacala & 193,343 & 116.00 & 0.60 & 40.00 & 34.48 & 2013 \\
Quelimane & 87,889 & 67.7 & 0.77 & 24.00 & 35.45 & 2013 \\
Macuba & 138,716 & 98.8 & 0.71 & 56.30 & 56.98 & 2013 \\
Pemba & 81,454 & & & & & 2015 \\
Chibuto & 65,173 & 38.7 & 0.59 & 11.00 & 28.42 & 2011 \\
Inhambane & 16,165 & 5 & 0.31 & & & 2015 \\
Namahacha & 200,000 & & & 70.00 & & 2011 \\
Tete & & & & & & \\
\hline
\end{tabular}


As concerns final management, it should be noted that there are either proper sanitary landfills in any Mozambican city, nor even in the capital, Maputo, where all the waste collected is disposed of without any treatment in a large open dump inside the city.

Excluding Maputo, where the local authorities are making concrete steps towards closing the municipal open dump and the construction of a modern sanitary landfill, no operational plan for waste management as developed between 2011 and 2015 envisages the construction of landfill within the next 5 years. The necessity to improve urban waste management is recognised, the risks for inhabitants' health and the environment are identified, but the documents recognise a weak financial viability of the municipalities and a low technical ability to design an integrated a sustainable waste management strategy.

In some cities, where the private sector is involved in extractive activities and exerts pressure to find solutions for the waste disposal, like Pemba and Tete, the local authorities seem more active and are supported by the government to find solutions and resources.

\subsubsection{Legal framework for waste management in Mozambique}

The main laws and regulations relating to the management of waste in Mozambique are as follows:

- National Environmental Policy, Resolution N. 5/1995;

- Environmental Law No. 20/97;

- Regulation on Bio-Medical Waste Management, Decree N. 8/2003;

- Regulation on Environmental Inspection, Decree N. 11/2006;

- Regulation on Solid Waste Management, Decree N.13/2006 revoked by Decree N. 94/2014.

- Technical Directive for the implementation and operation of landfills (2009);

- National Strategy for the Integrated management of urban solid waste in Mozambique for the period 2013-2025 (2012):

- Regulation for the management of hazardous waste, Decree 83/2014.

The most recent legal tools for waste management only came into force in March 2015, five years since extractive activities first began.

One of the general principles identified for hazardous waste management is the principle of self-sufficiency, according to which all the hazardous waste management operations have to be developed locally, in the national territory, avoiding, whenever possible, the transboundary movement. If this is not possible, the transboundary movements have to be made in accordance with the Resolution N. 18/96, which ratified the Basel International Convention and the Bamako Convention, which is supplementary to the Basel Convention for the movement of hazardous waste into or between signatory African countries.

The solid waste management is a duty of the municipalities with the exception of hazardous waste, which is the responsibility of MITADER and biomedical waste, which is the responsibility of the Ministry of Health.

\subsubsection{Hazardous waste in Mozambique: generation and treatment}

Hazardous waste is waste containing substances that are hazardous for health and the environment, thus requiring distinct management. The main steps to follow for correct hazardous waste handling are: identification, proper storage, labelling, transport and finally delivered to a licenced facility. All these steps have to be made without mixing hazardous waste with 
other waste, or with other types of hazardous waste, and, in accordance with local and international regulations, whenever possible, transboundary transportation must be avoided to prevent accidents (i.e. due to inconsistency between different national regulation, documentation and labelling or even international illegal trades).

By focusing our attention on hazardous waste generated by extractive sector in developing countries, it should be noted that frequently, where the extraction activity occurs, countries do not have a proper legal framework, infrastructure and technical capacity to handle the hazardous waste produced by the sector.

Mozambique has only one landfill for the disposal of hazardous waste, located in the south of the country, close to the capital Maputo. The Mavoco landfill was built in 2005 and has a total capacity of 75 cubic meters, equivalent to 70,000 tons. It has three cells and two basins for the collection of leachates, with a waterproof base in HDPE (High Density Polyethylene). It was built by the first big company operating in Mozambique since 1998, an aluminum smelter joint venture. The landfill belongs to the Mozambican government, under the tutelage of the National Fund for the Sustainable Development (FNDS), being the facility operated by the private sector. The Mozambique government has the responsibility of monitoring all the operations involving the transportation and treatment of waste. The first cell has now been closed, and the second cell is in use; the landfill receives on average 3,200 t/year of hazardous waste. The disposal fee in Mavoco landfill corresponds to $\$ 195 /$ ton, a very high value if we compare it with the rate charged for the same service in neighboring South Africa, which corresponds to $\$ 50 /$ ton [39].

In Mozambique, as is the case in many developing countries [40, 41], the absence of specific legislation, the lack of proper infrastructure and the weakness of monitoring systems, have allowed the incorrect treatment of hazardous waste.

We have analysed the current situation of the hazardous and non-hazardous waste in two significant Mozambican regions where extractive activities have increased in the last five years: Tete region, in the northwest of the country where coal is extracted through surface mining, and Cabo Delgado region, in the north east, where a massive offshore deposit of natural gas was found. It is outside the scope of our study to analyse the total quantity, respective composition and management of waste produced by the whole mining sector in Mozambique, yet we have considered the two emerging sectors that could be the driver for the improvement of hazardous waste management in Mozambique, due to their size and geographical localisation. In fact, both the areas are decentralised with respect to the only infrastructure existent in Mozambique for the disposal of hazardous waste, Mavoco landfill, which is located at more than $2,000 \mathrm{~km}$ from the extraction sites.

In 2011, when exploration of the mines began, Tete region was unprepared to treat the new waste, both in terms of strategy and infrastructure. Considering the local situation and the logistical difficulties, Vale Moçambique, one of the biggest active mining companies in the region, has built its own landfill and has contracted a private company to collect and dispose of the industrial waste from the mine. According to data released by the same company [42], the operational units in Mozambique in 2012 produced 61 million tons of mineral metallurgical refuse, 8 million of which were waste and 53 million inert, showing an increase of $69 \%$ compared to 2011. Regarding non-mineral waste, 19 thousand tons were produced in the same year, $8 \%$ of which were hazardous. The hazardous waste produced is mainly tires, waste contaminated with oils and grease, batteries and filters.

Concerning natural gas, the huge deposits discovered in 2010 are situated in Mozambique's northern offshore Rovuma basin, making the country the third-largest proven natural 
gas reserve holder in Africa, after Nigeria and Algeria [43]. U.S. company Anadarko and Italian multinational Eni are leading exploration activities in Mozambique's offshore Rovuma Basin and have made a joint venture to develop a project in Cabo Delgado province to liquefy and export the natural gas extracted offshore from both companies. According to data released by ENI [44], the recoverable gas reserves discovered are estimated at approximately $150 \mathrm{Tcf}$. We were unable to consult data about the quantity and type of hazardous waste produced offshore, but as reported in the LNG project, describing all phases of the developing plants [45], all solid waste will be delivered to the onshore facilities as an integrated part of the onshore waste management system. In fact, waste treatment facilities were built by the company in Afungi Peninsula in Cabo Delgado northern region, where all the non-hazardous waste will be treated [46]. While the non-hazardous waste is minimised, recycled and finally incinerated or disposed of in Afungi facilities, the hazardous waste is entrusted to third party contractors [47]. The project waste management facilities comprise incinerators and a non-hazardous landfill, which are necessary considering the lack of adequate landfill /disposal facilities in the vicinity of the project. Incinerators will receive non-hazardous combustible waste, as well as small quantities of hazardous waste, including oil impacted rags, oil filters, sludge, spill kits, paint cans and medical waste. The incinerators will be specified to meet current international best practice and local regulations, along with recognized emissions performance standards. The total quantity and leading type of hazardous waste streams are divided between the construction phase, which will produce 17,300 tons of hazardous waste, and the operation phase, which will generate approximately 350 tons/year. According to the project's waste management plan [46], these materials are correctly transported out of the country to proper facilities in full compliance with national and international legislation due to the difficulty in locating proper recycling or disposal options.

Hence, the two areas analysed have underlined the opportunities they represent for local communities, but also problems for health and the environment they will carry out, too, if hazardous waste will not be correctly managed. Nowadays, the absence of local facilities supporting the development, has pushed companies interested to not only extract natural resources, but also to keep a green image, to construct required waste management facilities for their production cycles. The Mozambique government plays the role of controlling the respect of local and international regulations. Such a strategic waste management approach allows the diffusion of manufacturing activities with the financial capacity of creating also infrastructures necessary for the development. Negligible is the diffusion of small medium enterprises that only the development of governmental waste management technologies, plants, infrastructure could support.

Moreover, leaving to private enterprise the management of waste could not push the reachable results to optimality. In developed countries, virtuous communities, as those described in [48], have supported the diffusion of well performing standards. Even if, now, in these first attempts of a structured, planned waste management Mozambique should manage the challenge of systems primarily satisfying a correct disposal, in the future also optimization of existing procedures should become a challenge to pursue.

\section{CONCLUSION}

The coal and gas rush in Mozambique could be a great opportunity for the country to leave poverty behind, yet it carries some environmental risks.

We have considered the increase of hazardous waste production, as a result of the extractive industry, like a driver for the improvement of waste management sector, instead of like a 
problem, due to the absence of supporting infrastructure. This point of view turns a challenge into an opportunity.

Before the coal and natural gas discoveries, waste management had already become more challenging, due to population growth and rapid urbanisation. Mozambique had a poor legislative framework, no infrastructure and weak technical capacity to manage the increasingly high quantity of waste. The arrival of international actors from the extractive sector has revealed the shortcomings and weaknesses of the waste management sector.

The necessity to handle large quantities and new types of hazardous waste correctly has prompted the waste management sector to alert the local government about the necessity to review and enhance the legal framework, to provide the country with a proper infrastructure and to facilitate policy makers, technicians and professionals.

Mozambique has only one landfill built to receive hazardous waste, which is located in the south of the country. Its capacity is low and partially exhausted and it has a disposal fee four times higher than in the neighbouring country, probably due to the lack of competition.

The main extractive projects are located in the north, more than two thousand kilometres from this one landfill site. The road network is deficient and in poor condition. These are the main reasons that force the extractive companies to export hazardous waste. However, transporting large quantities of hazardous waste for long distances on poorly maintained roads increases the cost of waste management and could increase the risk of environmental accidents. It would be better to treat and dispose of the greatest amount of waste as possible, both hazardous and non-hazardous, at the production sites. Thus the construction of at least two landfill sites for hazardous waste is necessary in Mozambique: one in the Tete region and the other in the Cabo Delgado region.

The local government has no financial resources to build facilities of this size, even for urban solid waste. In fact, as reported in municipal solid waste management plans, local governments are aware of the necessity to improve urban solid waste management, from open dump and burning to proper disposal, but with no plan developed in the last 5 years, is the construction of a landfill site envisaged, merely the identification of a suitable location for this purpose. The major constraint is the lack of financial resources.

Hence, public-private cooperation should be studied to utilize the capability of private international companies to support initial expenses and to partially recover invested money due to the fee required for disposal of waste of local communities or further private companies.

Surely, the construction of the landfill should be planned to avoid their multiplication, but minimise dedicated sizes, while improving actual waste management system, mainly characterised by uncontrolled dumping.

Mozambican government should direct its efforts in promoting firstly the correct disposal of waste and subsequently, in accordance with international guidelines, its minimisation. Nevertheless, development could not occur without awareness. Hence, the first steps should be dedicated to create a data base about the quantity and composition of waste produced in the country, to facilitate communication and coordination between all the actors, and to reinforce the technical capacity and ownership by local experts.

\section{ACKNOWLEDGMENT}

We greatly acknowledge the support of the Ministry of Land Environmental and Rural Development of Mozambique, the National Association of Mozambican Municipalities ANAMM and the International Lay Volunteer Association - L.V.I.A., for the support during the site visits and allowing the use of the data collected in the framework of the project 
"PROSIGRU" co-financed by the Italian Ministry of Foreign Affairs and International Cooperation.

\section{REFERENCES}

[1] United Nations, Johannesburg Plan of Implementation on Sustainable Development, World Summit on Sustainable Development, 2002.

[2] European Commission, Roadmap to a resource efficient europe, 2011.

[3] Tunesi, S., Conservare il valore. L'industria del recupero e il futuro della comunità, Luiss University Press, 2014.

[4] Myers, N. \& Kent, J., New consumers. The influence of affluence on the environment. PNAS, 100(8), pp. 4963-4968, 2003. http://dx.doi.org/10.1073/pnas.0438061100

[5] Behrens, A., Giljum, S., Kovanda, J. \& Niza, S., The material basis of the global economy. Worldwide patterns of natural resource extraction and their implications for sustainable resource use policies. Ecological Economics, 64(2), pp. 444-453, 2007. http://dx.doi.org/10.1016/j.ecolecon.2007.02.034

[6] WU Vienna, available at http://www.materialflows.net/trends/analyses-1980-2011/ reserves-of-non-renewable-materials-in-2011/, 2012.

[7] Fischer-Kowalski, M. \& Swilling, M., Decoupling: Natural Resource Use and Environmental Impacts from Economic Growth, UNEP, 2011.

[8] Dittrich, M., Giljum, S., Lutter, S. \& Polzin, C., Green economies around the world? Implications of resource use for development and the environment, 2012.

[9] International Mining for Development Centre. World Bank launches 'Billion Dollar Map' available at http://im4dc.org/world-bank-launches-billion-dollar-map/, 2014

[10] European Communities, Council directive of 12 december 1991on hazardous waste (91 / 689 / EEC ), Official Journal of the European Communities, No L 377 / 20, 1991.

[11] European Communities, Directive 2006/21/EC and amending directive 2004/35/EC, Official Journal of the European Communities, 2006.

[12] World bank, Mozambique Overview, available at http://www.worldbank.org/en/country/mozambique/overview

[13] UNDP, Work for human development, Briefing note for countries on the 2015 Human Development Report, Mozambique, 2015.

[14] Revenue Watch Institute, The 2013 Resource Governance Index, Mozambique, 2013.

[15] Lehto, T. \& Gonçalves, R., Mineral resources potential in Mozambique. Geological Survey of Finland, Special Paper, 48, pp. 307-321, 2008.

[16] Africa Progress Panel, Equity in Extractives. Stewarding Africa's natural resources for all. Africa Progress Report 2013.

[17] Frankel, J.A., The natural resource curse: a survey of diagnoses and some prescriptions. HKS Faculty Research Working Paper Series RWP12-014, John F. Kennedy School of Government, Harvard University, 2012.

[18] Africa Progress Panel, Grain, fish, money, Financing Africa's Green and Blue Revolutions, Africa Progress Report 2014.

[19] dos Muchangos, L.S., Tokai, A. \& Hanashima, A., Analyzing the structure of barriers to municipal solid waste management policy planning in Maputo city, Mozambique. Environmental Development, 16, pp. 76-89, 2015.

http://dx.doi.org/10.1016/j.envdev.2015.07.002 
[20] Dávila, J.D., Kyrou, E., Nuñez, T. \& Sumich, J., Urbanisation and municipal development in mozambique: urban poverty and rural-urban linkages. Final report, DPUUniversity College London, 2008.

[21] CMM, Plano Director de Gestão de Resíduos Sólidos Urbanos de Maputo, Municipality of Maputo, 2008.

[22] GTZ AGRESU, Relatório sobre a quantidade e composição de RSD no Município de Maputo e Projecções de Quantidade até 2021, 2010.

[23] Stretz, J., Economic instruments in solid waste management. Case Study Maputo, Mozambique, GIZ, 2012.

[24] Rotich, K.H., Zhao, Y. \& Dong, J., Municipal solid waste management challenges in developing countries-Kenyan case study. Waste Management, 26, pp. 92-100, 2006. http://dx.doi.org/10.1016/j.wasman.2005.03.007

[25] Parrot, L., Sotamenou, J. \& Dia, K.B., Municipal solid waste management in Africa: strategies and livelihoods in Yaoundé, Cameroon. Waste Management, 29, pp. 986-995, 2009. http://dx.doi.org/10.1016/j.wasman.2008.05.005

[26] Oyoo, R., Leemans, R. \& Mol, P.J.A., Comparison of environmental performance for different waste management scenarios in East Africa: the case of Kampala City, Uganda. Habitat International, 44, pp. 349-357, 2014. http://dx.doi.org/10.1016/j.habitatint.2014.07.012

[27] Oteng-Ababio, M., Arguello, M. \& Gabbay, O., Solid waste management in Africa cities: Sorting the facts from the fads in Accra, Ghana. Habitat International, 39, pp. 96-104, 2013.

http://dx.doi.org/10.1016/j.habitatint.2012.10.010

[28] Owusu, V., Adjei-Addo, E. \& Sundberg, C., Do economic incentives affect attitudes to solid waste source separation? Evidence from Ghana. Resource, Conservation and Recycling, 78, pp. 115-123, 2013. http://dx.doi.org/10.1016/j.resconrec.2013.07.002

[29] Conselho Municipal da Cidade de Lichinga, Plano de Gestão Integrada de Resíduos Sólidos Urbanos (draft), 2015.

[30] Conselho Municipal da Ilha de Moçambique, Plano de Gestão Integrada de Resíduos Sólidos Urbanos da Ilha de Moçambique 2013 - 2018, 2014.

[31] Conselho Municipal da Cidade de Nacala, Plano de Gestão Integrada de Resíduos Sólidos Urbanos do Município de Nacala 2013 - 2018, 2014.

[32] Conselho Municipal de Quelimane, Plano de Gestão Integrada de Resíduos Sólidos Urbanos do Município de Quelimane 2013 - 2018, 2013.

[33] Conselho Municipal da Cidade de Mocuba, Plano de Gestão Integrada de Resíduos Sólidos Urbanos do Município de Mocuba 2013 - 2018, 2013.

[34] Conselho Municipal da Cidade de Pemba, Plano de Gestão Integrada de Resíduos Sólidos Urbanos do Município de Pemba 2013 - 2018, 2013.

[35] Conselho Municipal da Cidade de Chibuto, Plano de Gestão Integrada de Resíduos Sólidos Urbanos (draft), 2015.

[36] Conselho Municipal da Cidade de Inhambane, Dreceção dos serviços urbanos, Plano Director Gestão de Resíduos Sólidos Urbanos no Município de Inhambane, 2011.

[37] Conselho Municipal da Vila de Namaacha, Plano de Gestão Integrada de Resíduos Sólidos Urbanos (draft), 2015. 
[38] Conselho Municipal da Cidade de Tete, Plano de Gestão Integrada de Resíduos Sólidos Urbanos, 2011.

[39] Sumalgy, D., Estimativa de riscos decorrentes de resíduos tóxicos no Parque industrial da Matola, University of Coimbra, 2011.

[40] HUNABITAT, Collection of Municipal Solid Waste Management in Developing Countries, 2010.

[41] Downs, M., Medina, M., A brief history of scavenging. In Comparative Civilizations Review, 2000.

[42] Vale Moçambique, Relatório de Sustentabilidade 2012.

[43] EIA Beta, U.S. Department of Energy, available at https://www.eia.gov/beta/international/analysis.cfm?iso=MOZ

[44] Eni Spa, Eni for Sustainable development 2014 progress, 2015.

[45] Anadarko Eni Moçambique Area 1 Lda, EIA Report for the Liquefied Natural Gas Project in Cabo Delgado. Chapter 4, 2014.

[46] Anadarko Eni Moçambique Area 1 Lda, EIA Report for the Liquefied Natural Gas Project in Cabo Delgado. Annex E - Waste Management Plan, 2014.

[47] Eni East Africa S.p.A., Request for expression of interest waste management services for Eni East Africa S.p.A activities in the Republic of Mozambique, 2015.

[48] Gamberini, R., Del Buono, D., Lolli, F. \& Rimini, B., Municipal solid waste management: identification and analysis of engineering indexes representing demand and costs generated in virtuous Italian communities. Waste Management, 33(11), pp. 2532-2540, 2013.

http://dx.doi.org/10.1016/j.wasman.2013.06.003 